\title{
Posouzení tepelně izolačních vlastností masivní dřevostavby pomocí termokamery
}

\author{
Assessment of the Thermally Insulating Properties of Solid Wood Building \\ Using Thermometer
}

\author{
Petr Fait ${ }^{\mathrm{a}^{*}}$, Josef Čech $^{\mathrm{a}}$, Pavel Král ${ }^{\mathrm{b}}$ \\ 'Vysoké učení technické v Brně, Ústav soudního inženýrství \\ ${ }^{b}$ Mendelova univerzita v Brné, ÚND LDF
}

\begin{abstract}
Abstrakt
Dnešní společnost se ubírá směrem k úsporám energií. S těmito úsporami velice úzce souvisí problematika tepelných mostů. Článek popisuje nebezpečí vyplývající z tepelných mostů vyskytujících se u staveb způsobené výrazně rozdílnými součiniteli tepelné vodivosti u použitých materiálů. Tyto tepelné mosty mohou způsobovat následně problémy při uživání dřevostavby. V článku jsou popsány místa s nejčastějším výskytem těchto tepelných mostů u masivních dřevostaveb. Následně je popsáno vlastní měření termokamerou FLIR E60 u dřevostavby v Nasavrkách u Chocně a měření je doloženo termografickými snímky s následným vyhodnocením. Článek se také zabývá předpisy potřebnými pro přesné měření součinitele prostupu tepla u posuzované dřevostavby. Př́íspěvek byl prezentován na konferenci ExFoS 2019 ve dnech 24.-25. ledna 2019.
\end{abstract}

Klíčová slova: tepelné mosty, termokamera, tepelná izolace, vady, součinitel prostupu tepla.

\section{1. ÚVOD}

Stavba dřevostavby v Nasavrkách, která byla stavěna svépomocí, byla zahájena v roce 2008 a následně dokončena v roce 2009. Na tuto stavbu majitelé použili borovicové hraněné řezivo tloušt'ky $20 \mathrm{~cm}$. Zpracované řzivo skladovali po dobu pěti let venku. Většinu činností potřebných $\mathrm{k}$ výstavbě hrubé stavby provedl majitel dřevostavby. V průběhu užívání této stavby, řešili majitelé množství problémů např. teplovzdušné vytápění dřevostavby, které vytápělo dřevostavbu nerovnoměrně a také částečnou výměnu jednoduchých oken za kastlová. [1] Cílem tohoto měření bylo zjistit a zaznamenat pomocí termokamery přítomnost tepelných mostu na problematických místech této dřevostavby.

\begin{abstract}
Todayś society is moving towards saving energy. These saving are very closely related to the issue of thermal bridges. The article describes the dangers arising from thermal bridges occurring in buildings caused significantly different coefficients of thermal conductivity for the materials used. These thermal bridges can cause problems in the use of wood buildings. The article describes the most frequent occurrences of these thermal bridges in solid wood buildings. Subsequently, the actual measurement of the FLIR E60 thermometer is described in the building in Nasavrky near Chocen and the measurement is documented by thermo graphic images with subsequent evaluation. The article also deals with the regulations necessary for the accurate measurement of the coefficient of heat transfer in the examined wood buildings. The paper was presented at the ExFoS 2019 conference, $24^{\text {th }}-25^{\text {th }}$ January.
\end{abstract}

Keywords: thermal bridges, thermometer, thermal insulation, defects, heat transfer coefficient.

\section{TEPELNĚ IZOLAČNÍ VLASTNOSTI DŘEVOSTAVBY V NASAVRKÁCH}

Jak je popsáno výše, dřevostavba $v$ Nasavrkách je postavena z borovicového hraněného řeziva tloušt'ky $20 \mathrm{~cm}$. Tato tloušt'ka $\mathrm{v}$ dnešní době, kdy je požadovaná hodnota pro součinitel prostupu tepla $U_{\mathrm{N}, 20}$ pro těžkou vnější stěnu (plošná hmotnost nad $100 \mathrm{~kg} / \mathrm{m}^{2}$ ) $\mathrm{U}_{\mathrm{N}, 20} \leq 0,30 \mathrm{~W} /\left(\mathrm{m}^{2} \cdot \mathrm{K}\right)$ neodpovídá normě. Pokud má tato dřevostavba splňovat tento normový požadavek na požadovaný součinitel prostupu tepla $\mathrm{U}_{\mathrm{N}, 20}$ musela by tato dřevostavba mít obvodové stěny tloušt'ky min $45 \mathrm{~cm}$. [2] Další problém u této dřevostavby nastává $\mathrm{z}$ důvodu nerovnoměrného sedání dřevostavby $\mathrm{v}$ průběhu jejího životního cyklu a tím vznikaní nerovností ve spojích 
a dalších styčných místech. Toto sedání je způsobeno nevhodným skladováním řeziva před zahájením stavby (zpracované řezivo bylo skladováno po dobu pěti let venku zakryté pouze maskovací sítí) a před zabudováním do stavby nebylo dostatečně vysušené.

\section{MOŽNÉ VADY ZPŮSOBENÉ TEPELNÝMI MOSTY U DŘEVOSTAVEB}

$\mathrm{V}$ důsledku použití materiálů $\mathrm{s}$ výrazně rozdílnými součiniteli tepelné vodivosti mohou u budov vznikat tepelné mosty, které zapříčiňují následné vady na těchto dřevostavbách. Hlavní příčinou těchto vad je zvýšená koncentrace vlhkosti v místech tepelných mostů, jejímž působením vznikají následující vady:

- Vytvoření plísně a následná nemožnost užívání těchto prostor $\mathrm{z}$ hygienických důvodů.

- Zvětšení objemu vlhkého prvku stavby, který může způsobovat nerovnosti v uložení těchto prvků nebo spojů a může docházet $\mathrm{k}$ následným únikům tepla netěsností obvodového pláště stavby.

- Při dlouhodobém působení vlhkosti na dřevěné prvky může docházet k výskytu dřevokazného hmyzu či dřevokazných hub.

\section{NEJČASTĚJŠÍ MÍSTA VÝSKYTU TEPELNÝCH MOSTŮ U STAVEB}

Jsou to místa na konstrukci, kde dochází k velkým lokálním odchylkách tepelných toků a tím vzniká nerovnoměrný teplotní gradient. Nejčastější místa výskytu tepelných mostů jsou zobrazena na obr. 1.

\section{MĚŘENÍ TEPELNĚ IZOLAČNÍCH VLASTNOSTI U DŘEVOSTAVBY V NASAVRKÁCH POMOCÍ TERMOKAMERY}

Termografie obecně znamená pořízení snímků měřeného objektu v potřebných vlnových délkách od $230 \mathrm{~K}$ do $310 \mathrm{~K}$, aby se zobrazilo teplotní vyzařování tohoto objektu.[4] Měřením termokamerou nemůžeme kvantifikovat tepelné úniky z důvodu nemožnosti měření součinitele prostupu tepla $U \mathrm{v}$ interiéru a exteriéru a dalších vlivů potřených $\mathrm{k}$ vyhodnocení tepelných ztrát. Použití termokamery je vhodné pro lokalizaci problémů, které můžeme následně vyhodnotit a hledat možnou nápravu těchto problémů. V následném řešení těchto problémů se může k přesnému vyhodnocení použít měřící zařízení, které nám pomůže přesně kvantifikovat tepelné ztráty. [2]

\subsection{Metodika měření termokamerou}

$\mathrm{Z}$ důvodu přesného nastavení termokamery před vlastním měřením je důležité kvantifikovat okrajové podmínky a tím eliminovat nepřesnosti při následném měření:

- Změření vzdálenosti měřených materiálů od termokamery.

- Změření povrchové teploty měřeného materiálu.

- Změření relativní vzdušné vlhkosti měřeného prostředí.

\subsection{Termokamera}

Termokameru FLIR E60 je nejvhodnější používat pro většinu aplikací ve stavebnictví:[5]

- Místo a stanovení rozsahu tepelných mostů.

- Kontrola kompaktnosti (těsnosti) obvodového pláště.

- Kontrola systémů TZB.

- Vlhkostní problematika. [6]

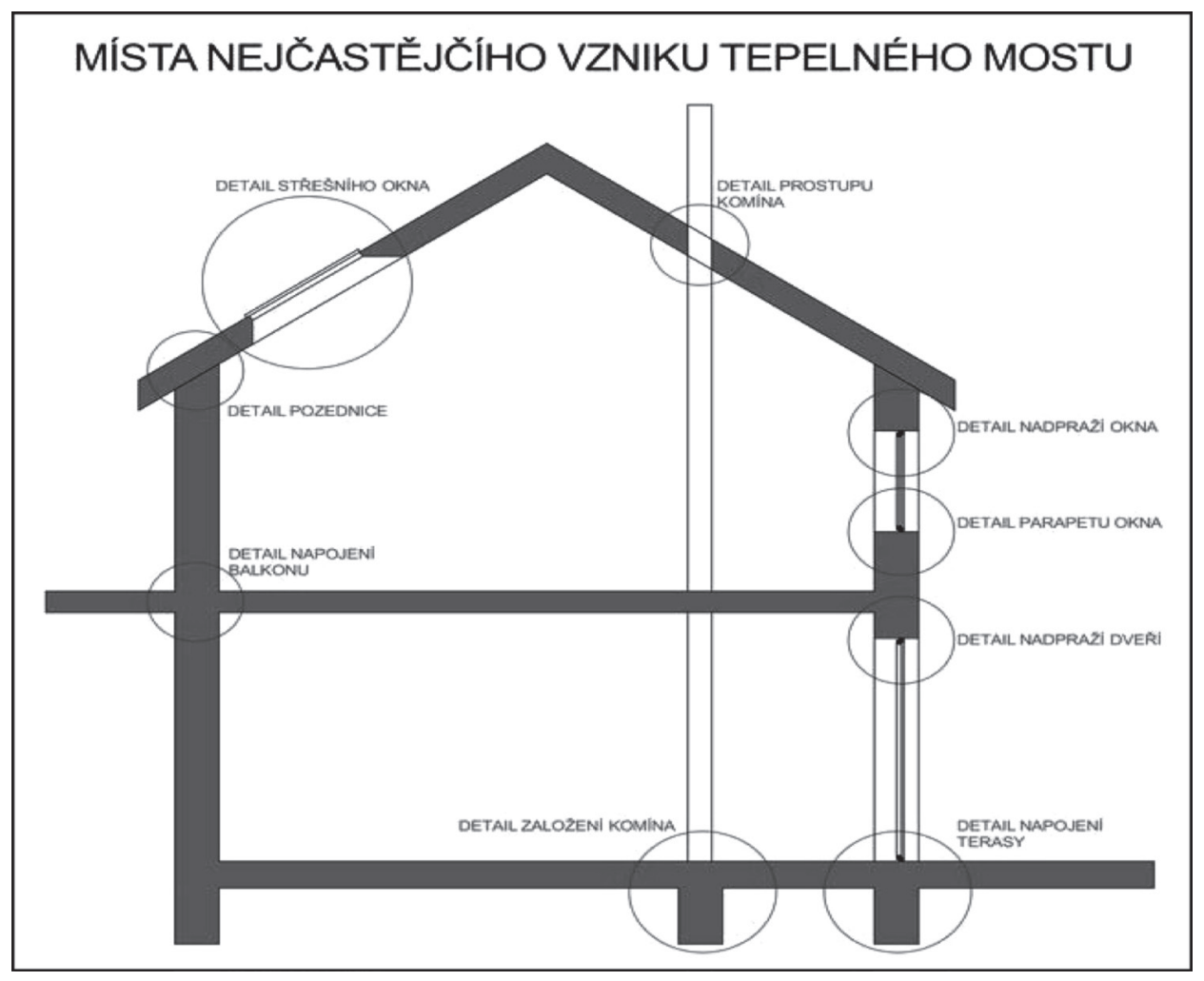

Obr. 1 Mista nejčastějšího vzniku tepelného mostu. [3]

Fig. 1 Places of the most common thermal bridge. [3] 


\subsection{Vlastní měření nejproblémovějších míst dřevostavby z pohledu tepelných mostů}

Před vlastním měřením byla $\mathrm{s}$ majitelem provedena vizuální prohlídka interiéru dřevostavby a byla navržena místa měření. Poté byl vytvořen nákres s přesnými body pro změření a zapsání okrajových podmínek z důvodu přesného nastavení termokamery.

\subsection{Vyhodnocení měření termokamerou a stanovení nejnižší povrchové teploty měřených objektů}

Nízká vnitřní povrchová teplota konstrukcí tvořících obálku dřevostavby má značný dopad na povrchovou kondenzaci vodních par a následné vady ve formě plísní. Po měření termokamerou je proto důležité určit nejnižší povrchovou teplotu měřených
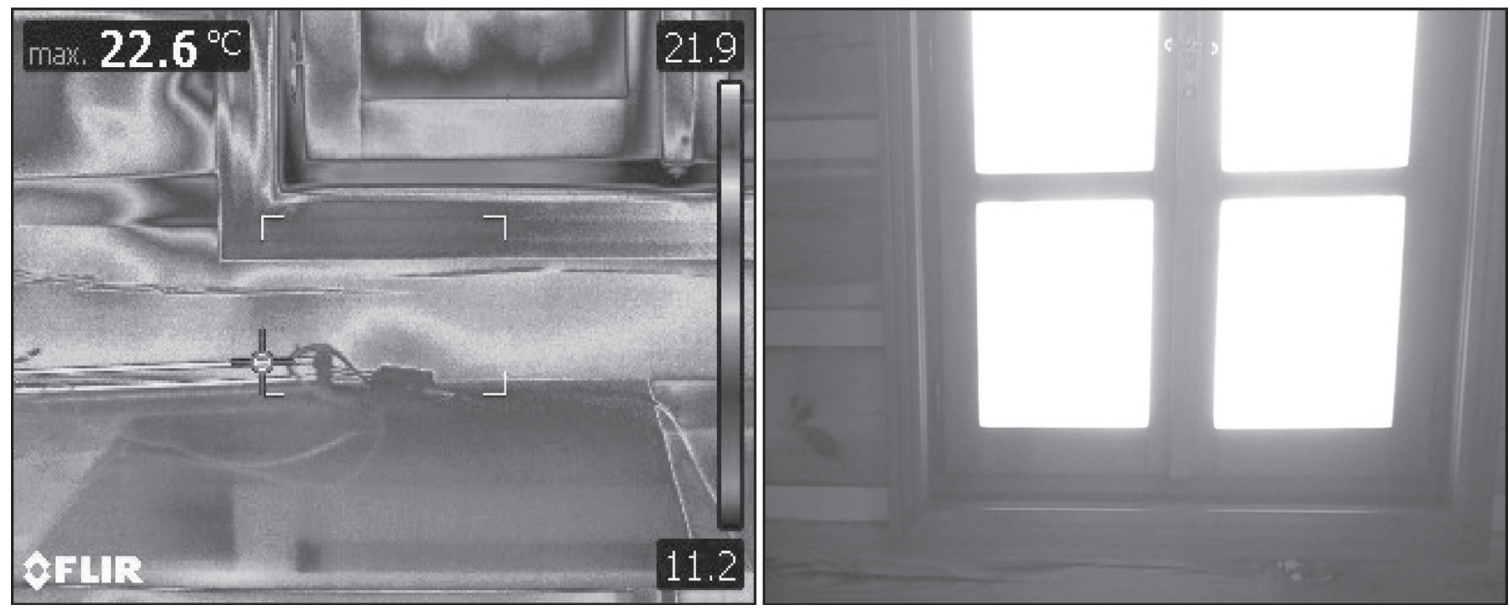

Obr. 2 Jednoduché okno vjídelně. [1]

Fig. 2 A simple windows in the dining room. [1]

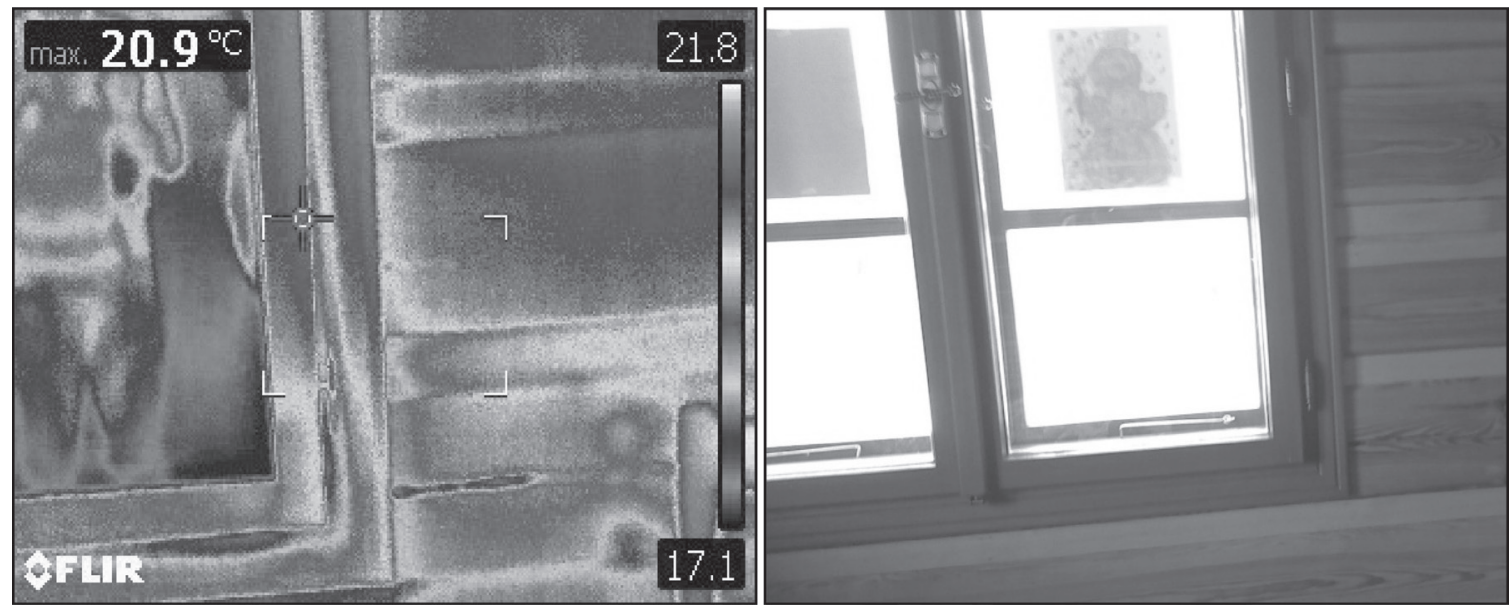

Obr. 3 Kastlové okno vídelně. [1]

Fig. 3 A doubled windows in the dining room. [1]
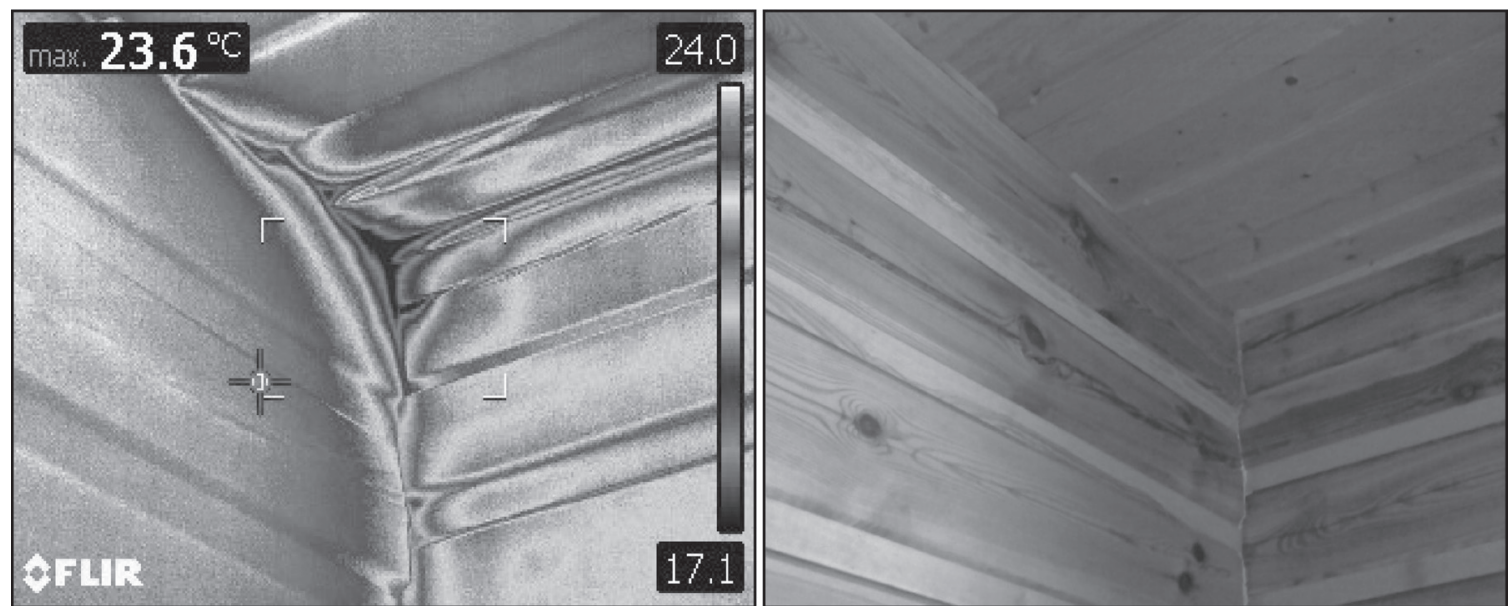

Obr. 4 Minimální teplota v rohu. [1]

Fig. 4 Minimum corner temperature. [1] 


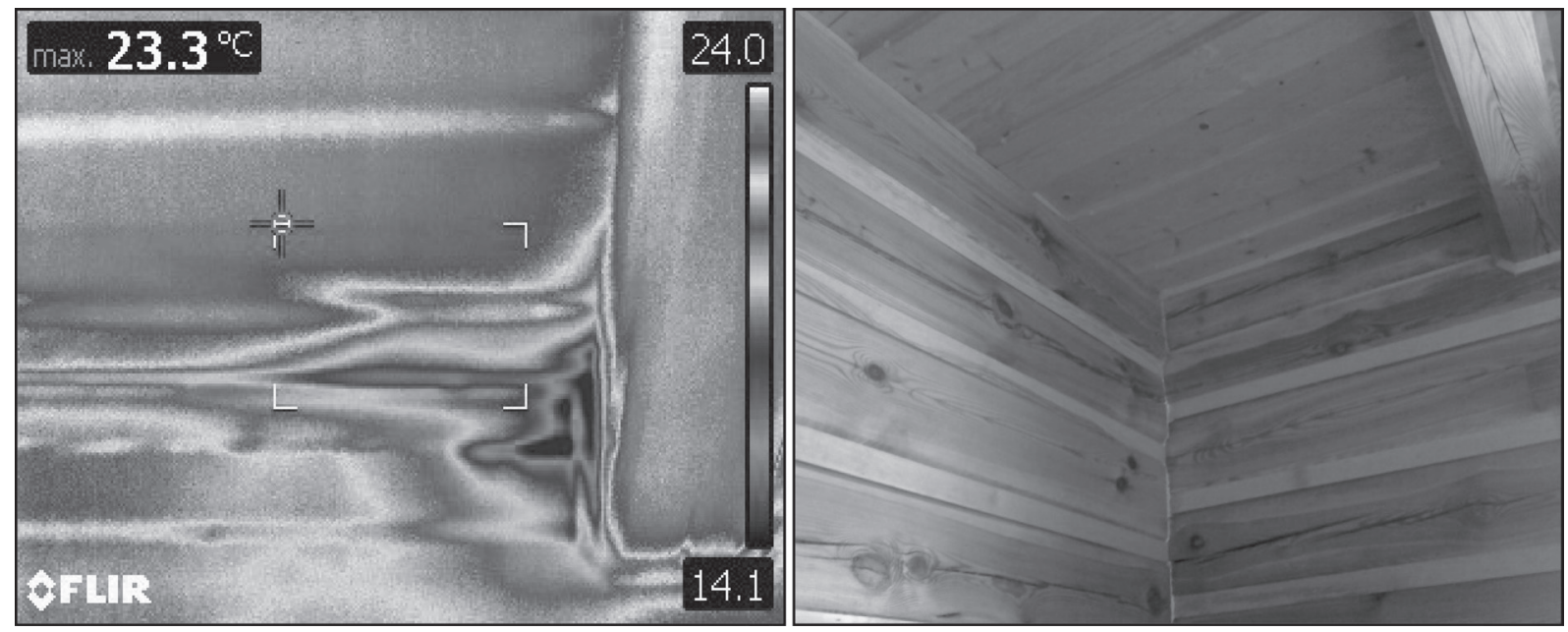

Obr. 5 Minimální teplota v rohu. [1]

Fig. 5 Minimum corner temperature.[1]

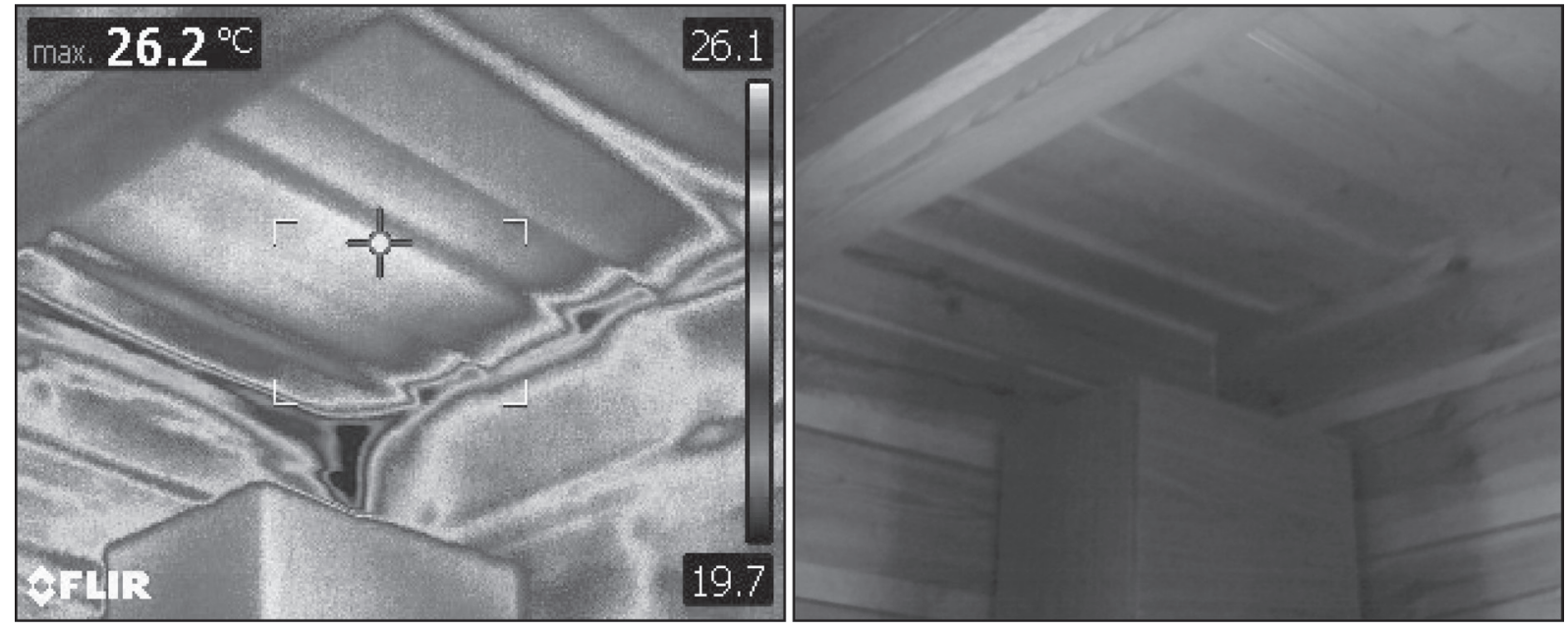

Obr. 6 Minimálni teplota v rohu. [1]

Fig. 6 Minimum corner temperature. [1]

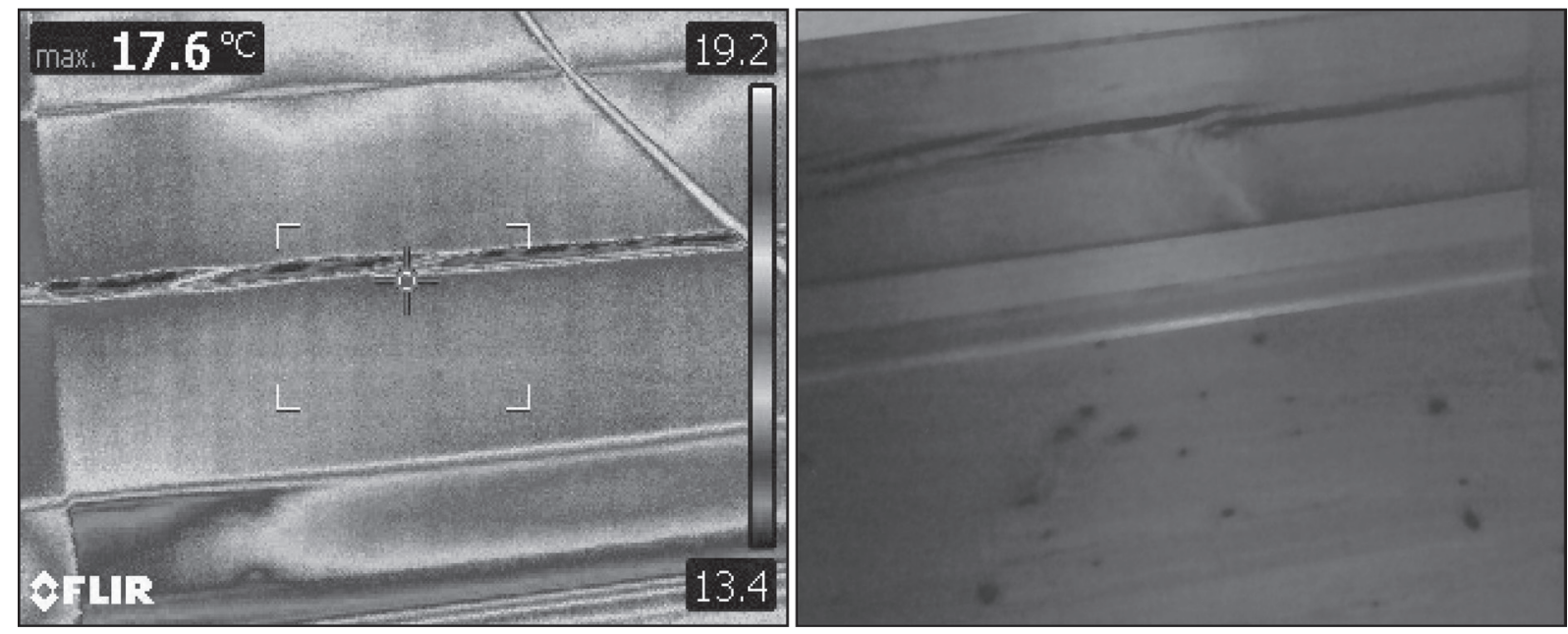

Obr. 7 Podélné trhliny trámu v ložnici. [1]

Fig. 7 Longitudinal cracks of the beam in the bedroom. [1] 
objektů. [11] Hygienické požadavky na tepelné mosty řeší norma ČSN 73 0540-2, která obsahuje tabulku kritického teplotního faktoru a tabulku nejnižších přípustných povrchových teplot. Naměřené nejnižší vnitřní povrchové teploty objektů s doporučenými nejnižšími príípustnými povrchovými teplotami dle ČSN 730540 2 jsou vyhodnoceny $\mathrm{v}$ tab. 1 . Teplotní faktor vnitřního povrchu dokumentuje vliv konstrukce a přstupu tepla $v$ určitém místě na vnitřní povrchovou teplotu nezávisle na teplotách přilehlého prostředí a je definován tímto vztahem:[8]

$$
f_{R s i}=\frac{\theta_{s i}-\theta_{e}}{\theta_{a i}-\theta_{e}},
$$

kde:

$\theta_{s i} \quad$ nejnižší vnitřní povrchová teplota ve ${ }^{\circ} \mathrm{C}$

$\theta_{e} \quad$ teplota venkovního vzduchu ve ${ }^{\circ} \mathrm{C}$

$\theta_{a i} \quad$ teplota vnitřního vzduchu ve ${ }^{\circ} \mathrm{C}$

$f_{R s i} \quad$ teplotní faktor vnitřního povrchu

V konstrukcích kde se uvažuje jednorozměrné šíření tepla, bude nejnižší povrchová teplota rovna průměrné vnitřní povrchové teplotě podle vztahu:

$$
\theta_{s i, \min }=\theta_{e}+f_{R s i} \cdot\left(\theta_{a i}-\theta_{e}\right),
$$

kde:

$\theta_{e} \quad$ teplota venkovního vzduchu ve ${ }^{\circ} \mathrm{C}$,

$\theta_{a i} \quad$ teplota vnitřního vzduchu ve ${ }^{\circ} \mathrm{C}$,

$f_{R s i} \quad$ teplotní faktor vnitřního povrchu,

$\theta_{\text {si,min }}$ nejnižší vnitřní povrchová teplota ve ${ }^{\circ} \mathrm{C}[8]$.

Z naměřených hodnot vyplývá, že všechny měřené objekty vyhovují z pohledu nejnižší př́pustné povrchové teploty dle ČSN 73 0540-2. Z obr. 2 a obr. 3 je zřejmé, že k největším tepelným únikům dochází u jednoduchého okna oproti kastlovému kde teplotní rozdíl mezi okny je $5,9^{\circ} \mathrm{C}$ a při celkovém počtu stávajících jednoduchých oken v dřevostavbě je celkový teplotní únik značný. U obr. 5 je nepatrný teplotní rozdíl mezi naměřenou nejnižší vnitřní povrchovou teplotou objektů a nejnižší přípustnou povrchovou teplotou dle ČSN 73 0540-2, který je $1,5^{\circ} \mathrm{C}$. Tento faktor může v budoucnu při zvýšené vlhkosti způsobovat problémy. Nejlepší hodnoty z měření jsou vyobrazeny na obr. 6 kde teplotní rozdíl mezi naměřenou nejnižší vnitřní povrchovou teplotou objektů a nejnižší príípustnou povrchovou teplotou dle ČSN 73 0540-2 činní $7,1^{\circ} \mathrm{C}$. Na obr. 7 je viditelná podélná trámová trhlina (způsobená nevhodným skladováním řeziva), a teplotní rozdíl mezi naměřenou nejnižší vnitřní povrchovou teplotou objektů a nejnižší př́ípustnou povrchovou teplotou dle ČSN $730540-2$ je $0,8^{\circ} \mathrm{C}$, což je nejhorší naměřený výsledek. Po vyhodnocení měření těchto kritických míst a konzultaci s majitelem byl navržen další postup:

- Porovnání tepelně izolačních vlastností jednoduchého okna oproti oknu kastlovému pomocí univerzálního měřícího zařízení datelogger ALMEMO 710 spolu s čidly na měření teploty vzduchu, povrchové teploty a tepelného toku.

- V místech tepelných mostů přetěsnění trhlin a netěsností s následným přeměřením termokamerou.

\subsection{PŘEDPISY SOUVISEJÍCÍ S VÝPOČTEM TEPELNĚ IZOLAČNÍCH VLASTNOSTÍ OKEN NA DŘEVOSTAVBĚ POMOCÍ UNIVERZÁLNÍHO MĚŘÍCÍHO ZAŘÍZENÍ DATELOGGER ALMEMO 710}

- ČSN 73 0540-1 Tepelná ochrana budov - Část 1: Terminologie - Norma vymezuje termíny užívané v oboru stavební tepelné techniky, definice veličin, jejich značky a jednotky popisující šíření tepla, vlhkosti a vzduchu stavebními materiály a konstrukcemi, popisující stav vnitřního a venkovního prostředí používané v ČSN 730540 - 2, 3 a 4. Termíny a definice veličin, jejich značky a jednotky lze použít i při aplikaci norem souvisejících, zejména uvedených v normativních odkazech normy a souvisejících normách. Norma sjednocuje a zpřesňuje termíny a definice v uvedených oblastech. [7]

- ČSN 73 0540-2 Tepelná ochrana budov-Č́st 2: Požadavky - Tato norma stanovuje tepelně technické požadavky pro navrhování a ověřování budov s požadovaným stavem vnitřního prostředí při jejich užívání, které zajišt'ují plnění základních požadavků na stavby, zejména hospodárné splnění základního požadavku na úsporu energie a tepelnou ochranu budov podle zvláštního předpisu a zajištění ochrany zdraví, zdravých životních podmínek a životního prostředí. Platí pro nové budovy a pro stavební úpravy, udržovací práce, změny v užívání budov a jiné změny dokončených budov. [8]

- ČSN 73 0540-3 Tepelná ochrana budov-Část 3: Návrhové hodnoty veličin - Norma stanoví národní normové, charakteristické a návrhové hodnoty fyzikálních veličin stavebních materiálů a výrobků, výplní otvorů, zdících

Tab. 1 Stanoveni nejnižši vnitřní povrchové teploty.

\begin{tabular}{|c|c|c|c|c|}
\hline \multicolumn{5}{|c|}{ Stanovení nejnižší vnitřní povrchové teploty měřených objektů } \\
\hline & $\begin{array}{c}\text { Naměřená nejnižší } \\
\text { vnitřní povrchová } \\
\text { teplota }\left[{ }^{\circ} \mathrm{C}\right]\end{array}$ & $\begin{array}{c}\text { Nejnižší př́ípustná } \\
\text { povrchová teplota dle } \\
\text { ČSN } 730540-2\end{array}$ & $\begin{array}{c}\text { Rozdíl teplot } \\
\text { ve }\left[{ }^{\circ} \mathrm{C}\right]\end{array}$ & Vyhovuje \\
\hline Jednoduché okno v jídelně (obr. 2) & 11,2 & 9,27 & 1,93 & ano \\
\hline Kastlové okno v jídelně (obr. 3) & 17,1 & 9,27 & 7,83 & ano \\
\hline Minimální teplota v rohu (obr. 4) & 17,1 & 12,6 & 4,50 & ano \\
\hline Minimální teplota v rohu (obr. 5) & 14,1 & 12,6 & 1,50 & ano \\
\hline Minimální teplota v rohu (obr. 6) & 19,7 & 12,6 & 7,10 & ano \\
\hline Podélné trhliny trámu v ložnici (obr. 7) & 13,4 & 12,6 & 0,80 & ano \\
\hline
\end{tabular}

Tab. 1 Determining the lowest surface temperature. 
prvků a zdiva, návrhové hodnoty veličin vnějšího prostředí, vnitřního prostředí a vzduchu pro navrhování a ověřování stavebních konstrukcí a budov z hlediska šíření vlhkosti a jejich tepelné ochrany podle ČSN 73 0540-4 a norem souvisejících. [9]

- ČSN 730540 - Tepelná ochrana budov - Část 4: Výpočtové metody - Hlavní text normy je členěn podle veličin hodnocených v ČSN 73 0540-2. Pro každou veličinu je uvedeno, co se výpočtem hodnotí, za jakých okrajových podmínek se provádí výpočtové hodnocení, jaké normy pro tato hodnocení zejména platí, co musí výpočtové hodnocení zahrnovat a jaké je zásadní členění použitelných výpočtových metod, popř. jak se při hodnocení postupuje u specifických druhů konstrukcí, včetně odkazů na podrobnější popis v prrílohách.[10]

\section{ZÁVĚR}

Cílem tohoto článku bylo provézt prvotní posouzení tepelně izolačních vlastností masivní dřevostavby v Nasavrkách pomocí termokamery. Při tomto prvotním měření bylo zjištěno, že všechny měřené objekty vyhovují z pohledu nejnižší přípustné povrchové teploty normě ČSN 73 0540-2. Z pohledu energetických úspor $\mathrm{v}$ dřevostavbě bude důležité ještě provést podrobnější měření u oken jednoduchých a kastlových. Toto podrobné měření by mělo být kontinuální a bude provedeno pomocí univerzálního měřícího zařízení datelogger ALMEMO 710 opatřeného vhodnými čidly. Pomocí hodnot získaných z kontinuálního měření se následně vyhodnotí tepelně izolační vlastnosti jednoduchého a kastlového okna, instalovaných v masivní dřevostavbě. Kontinuální měření by se mělo provádět po dobu nejméně jednoho týdne. V místech, kde byly naměřeny tepelné úniky, a které byly následně opravovány (utěsněny), se provede kontrolní měření těchto problémových míst pomocí termokamery.

\section{LITERATURA}

[1] FAIT, P. Prvotní průzkum masivní dřevostavby v obci Nasavrky. Sborník anotaci konference Junior Forensic Science Brno 2016. Vysoké učení technické v Brně, Ústav soudního inženýrství, Brno, 2016. s. 28-29. ISBN 978-80-214-5336-4.

[2] ŠUBRT, R. Tepelné izolace v otázkách a odpovédích. BEN technická literatura, Stavitelství. Praha, 2005.

ISBN 80-7300-159-4.

[3] Janoušková, L. Venkovský dům [online]. Venkovský dům, [cit. 6.1.2019]. Dostupné z: http://www.venkovskydum.cz/tepelnymost/

[4] Hollan, J. Termografické ověřováni tepelně izolačnich vlastnosti oken se speciálními roletami. Prríspěvek k dílně Nedestruktivní testování v technických oborech, FAST VUT v Brně, listopad 2005. Workshop NDT2005, proceeding p. 25-27. ISBN 80-7204-420-6.

[5] Hollan, J. Co chceme od termokamer [online]. MUNI, 2013. [cit. 6.1.2019]. Dostupné z: http://amper.ped.muni.cz/jenik/LWinfrared/termokamery_co_chtit.html

[6] ČSN EN ISO 13788:2002 (73 0544) Tepelně vlhkostní chování stavebních konstrukcí a stavebních prvků - Vnitřní povrchová teplota pro vyloučení povrchové vlhkosti a kondenzace uvnitř konstrukce - Výpočtové metody.

[7] ČSN 73 0540-1 Tepelná ochrana budov - Část 1: Terminologie.

[8] ČSN 73 0540-2 Tepelná ochrana budov - Část 2: Požadavky.

[9] ČSN 73 0540-3 Tepelná ochrana budov - Část 3: Návrhové hodnoty veličin.

[10] ČSN 730540 - Tepelná ochrana budov - Část 4: Výpočtové metody.

[11] OSTRÝ, M., BRZOŇ, R. Stavebni fyzika - tepelná technika v teorii a praxi. Vysoké učení technické v Brně, Brno, 2014. ISBN 978-80-214-4879-7.

[12] FAIT, P., ČECH, J., KRÁL, V. Posouzení tepelně izolačních vlastností masivní dřevostavby pomocí termokamery. Sborník př́spěvků konference Expert Forensic Science Brno 2019. VUT v Brnĕ, ÚSI, 2019. s. 273-282. ISBN 978-80-214-5708-9.

\section{Správná citace:}

Fait, P., Čech, J., Král, P. Posouzení tepelně izolačních vlastností masivní dřevostavby pomocí termokamery. Soudní inženýrství, 2019, 30(2), 19-24. DOI: http://dx.doi.org./10.13164/SI.2019.2.19. ISSN 1211-443X. 